\title{
Hegel and Marx on Individuality and the Universal Good
}

\author{
Charlotte Baumann
}

\begin{abstract}
Picking up on Marx's and Hegel's analyses of human beings as social and individual, the article shows that what is at stake is not merely the possibility of individuality, but also the correct conception of the universal good. Both Marx and Hegel suppose that individuals must be social or political as individuals, which means, at least in Hegel's case, that particular interests must form part of the universal good. The good and the rational is not something that requires sacrificing one's interests for the community or denying one's particular character so as to become an equal rational agent. Very much to the contrary, the rational or the common good is nothing but the harmonious structuring of particular interests. While Section I introduces Marx's and Hegel's conceptions of individual and social beings, Sections II and III discuss their respective views of individuality, and Sections IV and V discuss the notion of a universal good containing individual interests.
\end{abstract}

Marx famously proposes that citizens of the modern state live a 'double life, a heavenly one and an earthly one' - one in which they exist as 'communal beings' and one in which they live as 'private persons' (MEW 1: 355). ${ }^{1}$ Hegel suggests in a similar manner that individuals contain a 'dual moment' (PR: $\$ 264,287)$. While scholars like Hardimon (1994) and Neuhouser (2000) have looked into Hegel's conception of humans as individual and social beings, a central aspect of his reasoning has gone unnoticed-and it is precisely the one that Marx's criticism gets at. The point is not merely that human beings are both social and individual, and that society should enable their individuality and connect both roles (cf. Hardimon 1994: 164ff.). Marx's worry is not merely a psychological one, pointing to a form of self-alienation. His is a much more social or practical concern. Marx criticizes the concept of a two-sided individual, on the grounds that the one who has a say in or, at least, endorses political decisions is not the same person who acts, lives and has interests in the private sphere. Basically, Marx is claiming that if there is any distinction between humans as social and individual beings, then a society is necessarily only formally democratic and consensual, while the 


\section{Hegel and Marx}

common good remains an empty phrase unconnected to what actual individuals want and need for themselves.

Hegel and Marx are both systemic thinkers, with a keen interest in the functioning of social structures and institutions. It is precisely this awareness of the power of social systems and structures-the fact that they do not take individuality as a given, unproblematic starting point- that makes their discussion interesting. For Hegel and Marx, individuality must be treated more like a problem than a fact. The question of individuality concerns not only how individuality is possible within society, but also what political demands can be derived from individuality, and, more precisely, what role individuals should play in political decision-making and the definition of the universal good. If one regards human beings as instances of the same human essence, then the common good can be conceived as what furthers that essence (even if it is brought about by a benevolent dictator), or as what the majority of individuals decide by equal vote (supposing that the majority is most likely to grasp what is good for all). If you believe that human beings are diverse (or that this is required for their individuality), then you not only confront the problem of how this diversity is both enabled and threatened by society; you also have to acknowledge that individuals tend to have different or even opposing interests, which makes it much harder to say what would be best for all and implies that a majority vote necessarily misrepresents the diversity of interests.

Both critics and supporters of Hegel tend to interpret his state in terms of rational aims and plans according to which individuals are ordered by a benevolent government that knows what is rational or beneficial for individuals. Taylor (1975: 439) suggests the state is rational and individual freedom requires 'identifying with this larger life'. In Franco's words, 'the state is the objective embodiment of that substantiality and rationality that represents the deepest essence in human beings' (Franco 1999: 282). Patten (1999: 192) proposes that freedom requires 'subjectively identifying with the good of the community as a whole'. Pippin and Patten additionally claim that the state enables individuals to distance themselves from their immediate interests and desires, thereby becoming rational agents (Pippin 2008: 192; 2000: 160).

Both interpretations boil down to the demand that individuality-the particular interests, distinct needs and desires of individuals - must be excluded from the state, either by changing the individuals themselves or by having them endorse something whose value is not immediately linked to their personal well-being. Even Hardimon (1994: 211), who stresses the idea of a collective deliberative process, suggests that the common good is different from egoistic interests. ${ }^{2}$ Neuhouser maintains that only a disinterested elite can know the common good (Neuhouser 2002: 202, cf. 130f.). In fact, Neuhouser's proposition is only fitting: Normal citizens certainly do not, or do not 


\section{Charlotte Baumann}

necessarily, know the common good, if the reason that it is good is not down to an increase in their personal well-being, but rather some ethical or rational standard. Individuals can know this standard, it is supposed, only insofar as they are social beings and manage to abstract from their individuality-which entails the odd proposition that some individuals can be more social than others. This is precisely Marx's worry. Paraphrasing George Orwell's Animal Farm, just as no pig can be 'more equal' than others, so no individual can be 'more social' than others. That human beings are social and individual does not mean that they have two sides, which can be more or less developed. Rather, they are social as individuals; Marx demands that they should therefore be political decision-makers as individuals with their distinct interests, views, needs and desires.

While there is some basis for the interpretations of Hegel mentioned above, the present article will show that there are also very good reasons for reading Hegel as addressing precisely the issue Marx has raised-and, I believe, more successfully so. Marx thwarts his own aim of making individuals have a say in politics by under-developing the notion of individuality and how it is enabled by society. Hegel, on the contrary, provides a more realistic take on the possibility of individuality and shows how individual and group differences can make a meaningful contribution to political decision-making and the definition of the common good. To make this argument, I will first clarify the conception of individuality and sociality which the two authors have (I). I will then address the two aspects of the problem of individuality: first, how individuality is possible within society (II, III); and, second, how individual differences need to inform the common good for Marx and Hegel (IV, V).

\section{The particularity and universality of human beings}

In his Philosophy of Right, Hegel proposes that individuals have two moments. They are a 'singularity that knows and wills itself as separate (fïr sich)' and a 'universality that knows and wills the substantial' (PR: \$264, 287). As a first approximation one can say the particular aspect of individuals involves their ability to distinguish themselves from society, their awareness of being an individual, in the end: someone unique or 'singular', completely and incomparably different from anyone else. The universal aspect involves the individual's awareness that society or whatever surrounds her is also a constitutive element of herself. In terms of subjective development, the capacity to use language and to develop certain ways of comprehending the world can only evolve in communication with others and in a society that provides one with complex objects of thought. Additionally, in order to exist as a thinking being not merely inside one's own mind, somebody must notice the thoughts one has 
expressed. Alone in the jungle, a human being would neither in her own thinking evolve to be fully human, nor would she exist as a thinking being beyond her own mind, because no animal would notice that she is not merely enacting immediate instincts. ${ }^{3}$

While this provides a first approximation, it is important not to be misled in two respects. First, Hegel is speaking not merely of states of mind, but of what individuals 'know and will'. Hegel is thus speaking of what human beings act upon or what they decide and bring about collectively, thereby transforming it into a social reality. It is for this reason that Marx's account of the 'individual' and 'species life' of human beings (MEW 40: 539) is so relevant. The early Marx proposes that, in a post-capitalist society, the 'species' or 'communal being' of individuals refers to their 'equal participation in popular sovereignty' (MEW 1: 354). Human beings are universal in the sense that they see themselves as part of a community and enact this knowledge by participating in communal affairs or law making. Both Marx and Hegel attribute a particular importance to this communal life of individuals: Marx describes it as the true human nature (cf. $M E W$ 1: 355, 408), and Hegel speaks of the 'destiny of individuals' (PR: $\$ 258,276)$.

Second, while Hegel presents the two moments as opposites, they should not be misunderstood as two sides of individuals or two distinct ways in which they can think and interact with others. Rather, the two moments are contradictory aspects of one and the same relation that individuals have to society. This is, in a way, the central thesis of the present article, which will need to be proven over its course. For the moment it should merely be noted that 'willing oneself as separate' and 'willing the universal' are not necessarily mutually exclusive options. It is very well possible that being a distinguishable individual is only possible by identifying with one or several groups and social activities, and that wanting the common good cannot take any other form than wanting one's individual well-being - and agreeing to negotiate with other interest groups. Interestingly, while Marx is the one who insists that communal and individual lives must coincide, his conception of both appears to be much simpler than Hegel's, as this article will show.

\section{The private individual and Marx's inexpressible particular}

For Hegel, 'the individual actualizes herself only in becoming something definite, i.e. something determined and particularized' (PR: \$207, 238). Each human being must be a specific human being, with interests, experiences and arbitrary choices of her own. Otherwise, she would not exist as an individual. This so-called 'particular' aspect of human beings is lived, for example, in economic relations: Hegel 


\section{Charlotte Baumann}

starts his Philosophy of Right by discussing the arbitrary choices made when exchanging private property. Each individual's arbitrary choices are likely to differ from the choices of the next person, and they are present and visible in the form of her particular pieces of property. (That consumerism is a potent form of expressing and experiencing one's individuality is today even more obvious than it must have been in Hegel's time).

While Marx famously disagrees with Hegel on the question of private property, he also points out in The German Ideology that capitalism means progress for the individual, since the 'personal individual' is discovered in the private realm:

A nobleman always remains a nobleman, a commoner always remains a commoner, apart from his other relationships [this is] a quality that is inseparable from his individuality. The difference between the personal individual and the class individual, the accidental nature of the conditions of life for the individual appears only with the emergence of a class that is the product of the bourgeoisie. This accidental character is only engendered and developed by competition and the struggle of individuals among themselves. (MEW 3: 76)

For modern workers, there is a difference between their social role or profession and their existence as individuals - simply because of the fact that they cannot continue to do the same work for all of their lives. Competition and the lack of a means of income beside their own bodies force them to continually look for a new occupation, and it is mere chance as to where exactly they will end up working. The individual worker is therefore conscious that her personality does not coincide with her profession. This contrasts with the members of feudal societies, where individuals are only the 'specification of something universal' (MEW 3: 75f.), namely their guild or estate. As Marx puts it in his Grundrisse, 'individuals [are] imprisoned within a certain definition, as feudal lord and vassal, landlord and serf, etc.' (MEW 42: 96).

Marx welcomes the fact that capitalism introduces personal individuality, because human beings stop identifying with a specific social role or group, 'a limited human conglomerate' ( $M E W$ 42: 19), and are therefore able to identify with their humanity in general, their quality as a species-being. The problem is that one lives this personality only in the private and non-political realm. Marx therefore demands the liberation of the individual from class individuality in all spheres of life. Human beings should be like private persons in their productive and political activities too; that is to say, human beings should be well aware that none of their activities defines who they are. No one should have 'one exclusive sphere of activity'; everyone should fish, farm and criticize without being a fisher, 


\section{Hegel and Marx}

farmer, or critic (MEW 3: 33); everybody should participate in the organization of society in an equal manner (MEW 1: 253) and relate consciously to society as a whole in all their manifold activities. Marx's project in his early writings is to overcome the imposed reduction of human beings to mere functions of society, examples of social categories or groups. In fact, even in Capital Marx still maintains this criticism, as he describes individuals as 'bearers' of social functions, and proposes that communism has to enable the 'full and free development of each individual' (MEW 23: 618).

But what kind of individuality is Marx actually proposing? In a slightly unfair attack on Marx, one might ask: If nobody had an exclusive sphere of activity, if everyone fished, farmed, criticized without being a fisher, farmer or critic, participated equally in the organization of society-in what then would their particularity consist? This human being can be defined as a person whom none of its activities define socially, a particular to which no social categories apply, an unspeakable particular, which all individuals equally are-in the end: a universal. The very particular taken to the extreme is universal; claiming space for the particular is not giving it any.

This problem seems to have escaped many Marxist writers. Marcuse simply states that in communism all men have to exist as 'universal beings', and that 'the potentiality of the genus, Man', will be realized (Marcuse 1967: 275). Lefebvre claims that the 'total man' will be realized when 'the subject who is broken up into partial activities and scattered determination' overcomes this 'dispersion' (Lefebvre 1969: 162). Neither of them pauses to consider whether individuality would then continue to exist. They are concerned, as was Marx, with 'human emancipation', human beings realizing their nature as species-beings. As Leopold puts it: 'A species-being is an individual who has actualized-that is, developed and deployed-his essential capacities. By essential capacities, I mean those capacities that characterize the species, rather than those that might distinguish one person from another' (Leopold 2007: 184). The question of individuality is pushed into the background by Marx's focus on the 'universal development of individuals' (MEW 42: 91) in the sense of the development of all, as well as the sense of an unfolding of all aspects of human activity in each.

Nevertheless, Marx clearly did not intend the term 'particular species-being' (MEW 40:539) to be a contradiction in terms or contradictio in adjecto. He meant to propose that human beings shall be species-beings and yet also particular in some way and different from one another. The individual can be particularized socially, either by having a specific social function, which would trigger Marx's critique of a limited individual, or by her arbitrary yet socially recognized self-determination in a so-called private sphere. Individuals could also perform several social functions, which together would define them in the eyes of society. However, such a conception of a social being would again have to be rejected on the basis 


\section{Charlotte Baumann}

of Marx's argument against a split individual. The particularity that Marx has in mind must therefore refer to a certain naturally particular way in which one human being is universal, i.e., relates consciously to society and unfolds her manifold human abilities (cf. $M E W$ 40: 539).

But is this enough for the particularity of one individual actually to exist? The question may seem sophistical. After all, the fact that universals are needed to particularize a specific thing or person only applies to how one must necessarily think a particular, as opposed to how it is in itself, beyond knowledge. However, Marx is talking about thinking beings. The way they are known by others and see themselves coincides with how they exist as thinking beings. So to restate the same question differently: is this naturally particular way of carrying out one's daily activities enough for the particularity of one individual to be expressed in language, to be noticed by that very individual and others, and to be respected in society? It may be supposed that Marx thinks it is. If Chitty (2000: 182) is correct to propose that individuals recognize each other as speciesbeings in mutual production, then the moment of particularity may lie with the natural fact that, even though they all produce for society and carry out different and changing activities, every product is physically distinct from the other. However, this can only mark out one individual producer as different from the next if you suppose an initial private property of each person's product. In a collective process of production, it will be hard or impossible to link any particular product to any particular producer, both because of the similarity of mass-produced items and because the process of production is communal and involves several persons.

At bottom, Marx seems to be proposing that each individual can accommodate in her own mind the fact that she is a social being and yet also individual. For Hegel, as will be seen, a social definition of each individual is a limitation (of her infinite possibilities of self-definition), but it is also a liberation (of the particular will from an existence merely in terms of personal thoughts). In fact, from a Hegelian viewpoint, Marx's demand seems to have a similar status to that which Hegel attributes to Kant's 'categorical imperative' and the moral 'ought' that derives from a supposed moral essence. Marx's demand can be paraphrased as saying: 'Each individual shall produce in accordance with others and without being reduced to one or several of her productive activities'. Such a statement could well have the status of an 'ought' in Hegel's terminology, in the sense of an abstract demand that cannot be realized. This is so if one supposes that, in their actual practical relations, human beings will necessarily distribute tasks, even if it happens each day anew, and that individuals are bound to define themselves and one another to some extent by means of the particular labours they regularly or skilfully perform. That they shall not be defined by or limited to one or many social activities therefore seems to rely on the conception of a 
human essence, a true human being with manifold abilities, which ought to, but never can, actually exist in the world.

\section{Individuality as defined by society, the estates individual}

Consumerism certainly allows for a form of individuality for Hegel, as does what Hegel misleadingly calls 'moral subjectivity', i.e., the enacting of personal projects, intentions and aims, as well as one's own conception of the universal good. Yet the form of individuality that is socially most relevant pertains to social roles, in particular one's role as a professional and as a family member. These individual identities are more relevant as they are more stable and less diverse than one's consumer decisions and intentions-individuals freely choose their profession (PR: $\$ 262 \mathrm{~A}, 286$ ), but usually occupy it for some time, for Hegel. Additionally, one's identities as a professional and a family member are more likely to come into systematic conflict with the interests of others. Both aspects make those identities particularly interesting for Hegel. In the case of the family, Hegel is optimistic that conflicts of interests are avoided by love and one's immediate identification with one's role in the family. For this reason, professional groups and interests are my main concern here.

Hegel supposes that individuals need to have distinct social roles in order to be distinguishable and therefore individual. And yet he clearly shares Marx's concern about the split individual and the effects that such a split would have on a conception of the common good. Hegel aims at preventing the problem that the interests and actions of individuals as members of civil society are at odds with their interests and actions as citizens and members of the political state. He does so by making each individual a member of an estate or professional and political grouping.

Hegel's Philosophy of Right proposes that the best state requires not a parliament with political parties, but an 'assembly of estates'. The three estates are landowners, the business class, and the bureaucracy. The business class is the largest and most important class and it is divided into 'corporations' or professional groups akin to medieval guilds, whose interests are represented by delegates. While civil servants work in the executive and are not supposed to have any agenda, the other two estates make up the 'assembly of estates', which is the legislative body. There is some controversy as to how much power Hegel envisaged this assembly to have. However, there are good reasons for believing that the powers are very extensive: Besides making laws, the assembly also approves of the budget (E3: $5544,144 / 343)$. Hegel also argues that the estates coordinate their production and trading practices outside of parliament. The state can regulate prices and even, if necessary, 'determine everyone's labor' 


\section{Charlotte Baumann}

(PR: $\$ 236,262) .{ }^{4}$ The monarch for his part has the sole function of saying 'yes' (PR: $₫ 280 \mathrm{~A}, 323$ ), as Hegel famously claims. The king's final decision is merely symbolic, symbolizing the unity and free sovereignty or subjectivity of the state (cf. PR: \$273, 308f.).

What Hegel is sketching in the estates is clearly a particular universal being-or, in Marx's terms, a 'particular species-being' (MEW 40: 539). In fact, the estates enable human beings to be universal (or social) and individual at the same time, and they do so in three senses: (1) In the way pointed to, but under-theorized by Marx, the estates make sure each person or rather group participates in political decision-making in a particular manner. (2) Through negotiations in the 'assembly of estates', professional groups are able to make sure that their particular interests are taken into account when making laws and formulating the common good. (3) Hegel supposes that just as individuals need to be 'particular universal beings', so the public good in turn needs to be a universal that contains particulars, i.e., egoistic group interests.

(1) For Hegel, estates and the corporations 'mediate' between 'the people, which is resolved into individuals', and the government (PR: \$302, 342). In them, the individual 'comes into existence for the state' (PR: \$301, 341). The estates make the individual real as a social being primarily, as will be discussed in (2), because individuals can express their particular interests. However, the estates certainly also do so in the sense that different individuals participate in and identify with the social whole in a different manner. Marx's analysis presented above also suggests that each individual is bound to have an individual way of participating in the public good and in communal production. However, Marx opposes the idea that society should define the individuality of each, i.e., the specific and individual way in which one participates in law making and production. Hegel, on the contrary, proposes that the individual ways human beings participate in state affairs must themselves be social, i.e., defined by society.

Hegel proposes that the agricultural estate is personally represented in the legislative body, because agricultural property is handed down by birth and land owners experience their social relations as personal relations (PR: §305f., 345f.). The members of the business estate experience themselves in the market as separate from other individuals, but they come to identify with associations of shared economic interests. They are therefore represented by delegates, who belong to the same economic group as they do (PR: $\$ 308,346)$. Civil servants work for the state primarily in executive functions (PR: $\$ 303,343 \mathrm{f}$ ); these individuals identify fully with the state, while knowing it and its ends.

When reading Hegel, Marx worries that individuals are bound to overidentify with their social function. He thinks that individuals might work for the state unconsciously like ants. Marx writes in his Critique of Hegel's Philosophy of Right 


\section{Hegel and Marx}

that the member of the estate is like 'an animal that coincides immediately with its determination' (MEW 1: 285). In the Economic and Pbilosophical Manuscripts, Marx then goes on to define species-life as opposed to this animal life: 'The human being makes her life activity the object of her will and consciousness' (MEW 40: 516). In other words, human beings must know themselves as different from their social role. They have to reflect consciously on their social activities and, it may be supposed, society as a whole and 'will' or enact their critical insights.

But which exact ability of human beings is at stake here? If Marx is pointing to a psychological problem, then his case is quite weak and contradicts his own observation regarding modern individuals being 'split' into many roles. Marx himself has suggested that modern individuals have several distinct roles, which seems to imply that they are well aware that none of those roles completely define them. Hegel certainly links the particular roles they have in social production to a particular way of participation in state affairs; additionally, for the smallest group of citizens, namely civil servants, their working life and their political participation immediately coincide. And yet, the individuals Hegel describes are nevertheless modern in Marx's sense and have a manifold of other roles and spheres of interaction: they are moral beings developing their own conception of a moral good and enacting their purposes and life projects; they are independent consumers, they own and exchange private property and they are family members and citizens. Additionally, they can choose-and change-their professional occupation. With so many distinct roles and spheres, it can hardly be said that their membership in an estate dominates all aspects of their lives, making them incapable of conceiving of themselves in any other way than as instances of their estate or professional group.

Marx's main misgiving must be that Hegel turns individuals into cogs in a machine-not so much because they are incapable of independent thought, but because the machinery does not enable them to act on their critical insights. Hegel certainly proposes in the preface of the Philosophy of Right that the structure of the state must justify its existence to 'free thinking' (PR: 11/14). That is to say, the philosophical reader of his book must be able to understand the state, and Hegel hopes that she will become convinced that Hegel is indeed expounding a rational social order. But where is the scrutiny of the state, the criticism of a given conception of the common good located within the state? Individuals as moral subjects can completely question the social order $(P R: \$ 138,166)$ and formulate their own conception of the universal good. Yet Hegel defines 'morality' as the sphere of uncoordinated individual actions, which, precisely because they are uncoordinated, cannot affect the social order (and even if they could, moral subjects only follow their own private conception of the universal good and lack any secure standard or communicative method to determine what is right). As consumers and private property owners, individuals do not make demands on 


\section{Charlotte Baumann}

the state, and as members of the estates they either pursue their own egoistic group interests or need to be dedicated to the given aims of the state as civil servants (cf. PR: $\$ 294,332 f$.). (Unlike the collective individuals envisioned by Marx, those bureaucrats also lack any practical experience of what is of concern in their society.)

That Hegel turns individuals into cogs in a machine is not only or primarily problematic because human beings ought to be different, namely, thinking beings who act with consideration. It is also problematic because a state of ants is governed by instinct rather than reasoning and critical discussion. If human beings act as if they were animals or parts of machinery, no critical reflection on state affairs can happen or, at least, can have an effect on the state. After all, if individuals cannot formulate the universal good and critically evaluate the social system, who can? One needs to suppose either a machine maker-God or a rational and benevolent dictator-or some kind of unguided yet rational mechanism. It thus remains questionable how the social structure that Hegel proposes can be properly rational unless it is rational to and for individuals and can be challenged by them.

\section{Universal good and particular interests}

The discussion so far suggests that Marx's worry is the following: Within Hegel's conception of the state, individuals contribute to state affairs as members of estates. Yet, in this role, they are necessarily unable to act on their critical insights about the state and their roles, because they are either institutionally obliged to do whatever the state demands, or they are merely concerned with their egoistic group interests rather than the universal good.

It is time to turn to the second and third forms through which Hegel enables individuality within state affairs: (2) the representation of particular interests; and (3) his conception of the common good. Interpreters usually focus on civil servants to salvage the idea of a universal good in Hegel, just as Marx does. However, the key question is whether the pursuing of particular interests by business-people and landowners cannot at least partly coincide with ensuring the rationality of the state. Of course, one can argue, as Marx does, that it is impossible to make a relevant input to the public good by criticizing the state for not furthering one's particular interests. However, this claim is based on the implicit assumption that the public good must be something beyond individuals' interests. If the universal good were independent of the individuals' differing interests, then Marx would be right to conclude, as Avineri suggests, that the relation of economic groups to the state are a 'sin against the state's presumed claim to express the universal' (1972: 104). And Marx would be right to demand 


\section{Hegel and Marx}

that everyone should participate in the state in the manner in which civil servants do, dedicating oneself to the public good completely, so that all differences of interests disappear (MEW 1: 253, cf. 284).

The estates certainly represent particular forms in which individuals are universal in the additional sense that individuals belong to a particular universal, i.e., a particular professional group. Hegel could be proposing that the estates 'mediate' between civil society and the state in that they provide a first sense of belonging, which is then transferred to the nation as a whole when one acts as a patriotic citizen (cf. Bowman 2012: 50f.). However, this neither explains why the estates are represented in the 'estates assembly', nor why Hegel opposes a democracy, where individuals count as equal votes rather than distinct professionals. ${ }^{5}$

In fact, the whole idea of a 'particular universal being' that Hegel develops would be a sham. The proposition that individuals identify with the social in a particular manner would be a means of tricking individuals into identifying with something that is actually completely unrelated to their particular interests and needs. The group interests and estates would be a mere make-believe, making individuals think that their group interests matter while actually they do not. The estates as a mere stepping stone on the way to patriotism would serve the purpose of overcoming individuality and social differences, rather than including those differences within state affairs. The universal good, for its part, would be something abstract and empty, something beside the particular interests, needs, and relations of individuals. The state and the public good it provides would be what Hegel calls a 'particular universal' in the negative sense of a whole that does not contain the particularities (e.g., interests and individuals) it is meant to contain.

I have proposed as point (3) that Hegel's argument must be different. It only makes sense to propose that estates and professional groups are presenting their interests in the 'assembly of estates' if their interests are part of the universal good or what the state aims at bringing about. The individual as a particular universal being must be accompanied by a universal that contains particularity, i.e. a universal good that contains particular interests. In Hegelian terminology, this is called a 'concrete universal' (see Baumann 2011). In fact, I propose, the aims of the state and its rationality consist in nothing but uniting individuals in an organic social system to the effect that different social groups or 'organs' are related in a mutually beneficial manner. The universal good is certainly more than the mass of particular interests, but this 'more' only consists in the systematic and harmonious organization of those interests, which as such elevates them into parts of a system Hegel considers rational.

This is a rather novel interpretation. As mentioned in the introduction to this article, most interpreters propose that the universal good excludes particular 


\section{Charlotte Baumann}

interests. Pippin, Patten, Franco and Taylor make this claim, as do even Neuhouser and Hardimon. Beiser is a rare exception, as he points out that the plurality of interests is an important aspect of Hegel's organicist conception of the state (Beiser 2005: 242); but even he primarily regards state institutions as the organs of the state (253). And he does not make the point that the universal good would remain abstract or empty unless it consisted of nothing but the organic interrelation of particular interests.

Hegel proposes repeatedly that the organs of the state are not primarily the state institutions, but the estates (PR: $\$ 302 \mathrm{~A}, 343){ }^{6}$ Hegel writes, for example:

It is not in their unorganic form as singular human beings as such (in the democratic mode of voting), but as organic moments, as estates, that they enter upon that participation [in the state]; a power or activity within the state shall never appear and act in a formless, unorganic shape, i.e. out of the principle of maniness and mere numbers [Menge] (E3: \544, 144/343).

Moreover, in the Pbilosophy of Right, Hegel also opposes implanting in the organism of the state a democratic element devoid of rational form' (PR: §308, 347), and argues that individuals must enter the state as members of the estates. In an early political piece, Hegel opposes an organicist state to a mechanistic or 'machine' state (VD:22/481): The latter is a 'spiritless' administrative state where a 'formless mass' of atomistic individuals is 'regulated from above' (VD: 25/ 484). The rulers feel an 'illiberal jealousy of the independent command and organization of an estate, corporation etc.' (VD: 22/481) and do not allow for 'the participation of one's own will in universal affairs' (VD: 23/482).

If Hegel indeed demands that the state should be an organism in the sense expounded here, then this affects Marx's worry in two respects. In fact, one can say that it changes, in two respects, the sense of rationality that is at play, both regarding the individual's rational and critical stance toward society and the rationality of the social order and the universal good it furthers. First, it is not necessary that everybody be like a civil servant as Marx suggests—dedicating herself to the common good rather than her particular (group) interests. Nor does one have to suppose, as Neuhouser (2002: 202, cf. 130f.) does, that only an elite is able to know the universal good, namely civil servants without any interests of their own. To have an insight into the universal good does not require taking a distance from one's particular interests and analysing society with due detachment. Rather, the very defence of one's particular interests contributes to the harmonious coordination of interests, which, if done successfully, is the universal good. Being an egoist and pursuing the common good coincide-if one aims at furthering one's own interests within a harmonious interrelation of interests. 


\section{Hegel and Marx}

Second, the universal good and, in fact, the rationality of the state are structures that involve particular interests, rather than consisting in some content, ideal or norm divorced from those interests. It is notable that Hegel uses the terms formless, unorganic, and irrational almost interchangeably in the abovecited passages. The reason is certainly that the rational form, the famous absolute form that Hegel develops over the course of his Logic, includes the organism as a key element. Even though it is impossible to include any sufficient discussion of Hegel's Logic here, it may be supposed that the very organic organization of different interests is as such rational for Hegel, the actualization of a rational structure. The public good requires doing what is rational. The public good thus does not consist in a content beside the interests of individuals; it is nothing but the rational and organic structuring of those very interests.

\section{Problems with an organic conception of the social good}

It is clear that such an interpretation faces at least two serious challenges. First, an organic conception of the state does not necessarily empower individuals. In fact, Hegel's organicism is usually read in the opposite manner, namely as a way of turning individuals into 'bearers' of social functions (to use Marx's terminology). To make matters worse, Hegel speaks not only of the organism of the state, but also of its self-willing and self-conscious 'subjectivity' (PR: \$270, 290f.; \$257, 275). I have argued above that Hegel salvages individuality by allowing individuals to identify with particular groups and making demands on that basis. One could, however, propose the opposite and claim that Hegel is denying their individuality and reducing them to aspects of the state-organism or means for the ends of the state-subject. Hegel could salvage individuality by turning human beings into distinct functions within a state-which certainly makes them individual in the sense of distinguishable by means of their distinct social roles, but deprives them of individuality in the stronger sense of a particular personality developed in their interactions with others. Hegel's insistence that individuals must be socially distinguishable-which was presented as an advantage over Marx's position above - could entail a denial of individual self-determination, the free and social shaping of one's own individuality.

The second concern relates to the rational social order and the possibility of criticism mentioned above. Criticizing the fact that one's particular interests are not being met can certainly be a relevant critique of society, if the coordination of interests is part and parcel of the public good, as was argued above. However, the question remains as to whether one can also criticize the very idea of a social organism, rather than whether the organ with which one is associated is receiving all its necessary lifeblood. If the criticism upon which individuals can act 


\section{Charlotte Baumann}

concerns mostly the improvement of the social organism rather than the worth of such a system, then the question arises: on what basis can the organism as a whole be said to be rational?

Let us turn to the first concern. There is one key difference between my interpretation and critical accounts of the organism. Critics suppose that the organism distributes pre-given functions to individuals and groups. Individuals only have the function of actualizing or maintaining the predetermined, rational structure and given order of the state. On my reading, on the contrary, Hegel argues that the interests and interactions that individuals already have should be organized in an organic or mutually beneficial manner. Additionally, the organism is accompanied by the notion of collective subjectivity in Hegel, where the members of the 'estates assembly' (as the collective subject) oversee and regulate their own objective or social relations so as to ensure that they are truly organic and mutually beneficial. On my reading, Hegel is supposing that social relations always acquire some pattern as a matter of fact and there are always different roles played by different individuals or groups. The most rational social order is the one where not only individuals have to abide by the standards of their roles and social norms, but inversely those roles are shaped by and negotiated between social groups.

The above-cited passages support my interpretation. Hegel claims that the organism enables existing economic groups to participate in state affairs. He does not claim, inversely, that the idea of an organism or self-differentiated whole leads to the creation of functions, which individuals subsequently have to fulfil. The interpretative disagreement thus regards the relation of matter and form in Hegel: Is Hegel applying a specific, supposedly rational form to social relations like a stencil or mould, forcing matter (in this case, human beings and their relations) into a shape that is alien to it? Or is the form meant to pick up on the matter's own form, organizing the existing groups and types of individuals (namely their existing differences and interrelations) into a coherent and mutually beneficial system.

(A similar question can be asked regarding the subjectivity of the state: Does Hegel have a specific shape in mind, 'unity in difference' or self-consciousness, which ought to be realized in social relations? Or is Hegel's definition of state-subjectivity picking up on a factual aspect of statehood? If there is a functioning state, society is by definition a self-determining subject insofar as the society or state, represented by the government, makes the laws it follows. If this is Hegel's basic thought, the question then turns out to be how the modern state-subject he endorses differs from other historical states, like the benevolent dictatorship Hegel associates with Ancient China. There are good reasons to believe that, unlike Ancient China, the modern state is a collective subject for Hegel, where individuals collectively make laws in the estates assembly. This view is not only supported by the fact that Hegel regards the Greek polis as the first state proper, ${ }^{7}$ but because he claims in his Logic that subject and object of 


\section{Hegel and Marx}

absolute subjectivity must be identical, i.e. the ones who regulate social interactions and must be identical to the object of those state-interventions, namely the citizens or groups and their relations).

While it is impossible to discuss form and matter in Hegel in any sufficient manner, it can be noted that Hegel first proposes a conception of 'formed matter' (WL 2: 454/93f.) in his Logic, claiming that matter has its own form, i.e. given distinctions, which the relations and the structuring of the form have to take into account. In fact, he develops this question in different versions throughout his Logic and the argument culminates with the transition from the external end to life or the organism. The basic point is that imposing a purpose, structure or design on something else is not only "violent" (WL 2: 746f./452f. cf. 721/421), but also bound to fail, since one merely represses rather than incorporates the distinctions and properties the matter had in its own right. A truly all-encompassing or 'absolute form' cannot consist in the imposition of a pre-given shape or structure; rather it must consist in nothing but the structured relations of given matter, like the organism which is nothing but organic interrelation organs establish among themselves. In the passages quoted in section IV, Hegel opposes the idea that individuals are a 'formless mass' (VD: 25/484) that must be formed by the state; he opposes the view that human beings should participate in public affairs in a 'formless, unorganic shape' as 'mere numbers' of votes (E3: \$544, 144/343). Individuals, while being the matter of state regulation, also have a form for Hegel, namely given distinctions and interests. To a large extent, the rational state is nothing but the organic interrelation of those interests.

Let us then turn to the second concern: On what basis does Hegel claim that the type of state he describes is the best state possible? If an organic order is best for Hegel because his Logic shows it to be, this may trigger another of Marx's worries closely linked to the previous discussion: Hegel seems to be applying to the state a logic that is external to it and which cannot therefore prove the latter's worth (MEW 1: 213). Additionally, even if the Logic helps reveal something that is at work within a social order, Adorno's remark still applies, namely that 'the supposedly higher concept of spirit has to prove itself to the living and actual spirits of human beings' (Adorno 2006: 70). The state has to be rational not only in some metaphysical sense, but also to and for human beings. Or does it not?

Hegel's logical metaphysics suggests that there are a limited number of structures that are at work in the world and which solve the problem of unity in difference, plurality and oneness, in objectively better or worse ways. The Logic analyses structures in the abstract that are also at work in mind-independent nature, human thinking and social relations and allows for their evaluation. The organism, and, in fact, absolute subjectivity, are central elements of the best form of organizing diversity into a coherent whole, according to Hegel. This means: Hegel's logical discussion of the organism is inherently linked to the 


\section{Charlotte Baumann}

problem of individuality or individual differences and how they can be allowed to flourish and interact in a beneficial manner.

Does the metaphysical or logical worth of a system (as a solution to the problem of unity in difference) compel individuals to approve of it or to create such a system over the course of history? No. Hegel does not suppose any absolute necessity in the realm of human freedom (cf. VR1: 90/14). ${ }^{8}$ In other words, human beings are of course able to organize their lives in a different manner from the one suggested by Hegel, both individually and collectively. However, Hegel believes that the most rational thing to do, and what would enable the greatest amount of freedom, would be to organize society as an organic state (and, indeed, a collective, absolute subject). For Hegel, modern individuals are capable of coming to this conclusion, and he is optimistic that they will. However, their insight is not a necessary condition for the organic state being the most rational social order. In other words: the worth or legitimacy of an organic state is metaphysically warranted, but not its existence, since human beings may fail to recognize its worth.

This certainly sounds problematic. How can something be legitimate without the approval of its participants? First, one thing needs to be borne in mind: The social order Hegel proposes enables individual groups to make specific demands within the assembly of estates, and to oversee and coordinate their interests to their mutual benefit. The coordination of their interests and demands is part and parcel of the rational order of the state. In fact, one could say that Hegel empowers individuals to a much greater extent than they are empowered in a representative democracy or by means of participating in public discourse: One person's vote only minimally affects the outcome of an election; the disapproval that someone voices rarely has an effect on the social order. Hegel proposes, on the contrary, that individuals-organized in professional groupings-should negotiate and make the laws that benefit their interests. Additionally, Hegel proposes safeguards for personal rights and types of individuality that do not require or allow for negotiation. And the concept of an organism, in principle, requires that new types of individuality that emerge will also have to be included in a harmonious manner.

One could thus try to salvage Hegel by pointing out that individuals are likely to approve of an organic social order, either because they realize its inherent worth or because they have the power to ensure that their particular interests are furthered. However, an insightful point to take away from Hegel's discussion is that neither legitimacy nor the universal good should be understood as formal matters. Legitimacy and the good do not hinge on the fact that individuals approve or that what the state pursues can be taken to be good for all. The universal good is a question of content, of what material and other benefits individuals have and which aspects of their lives they have the power to shape. 
The formality of looking for individual approval of a social order becomes obvious not only when you consider that it is likely to be an imagined approval in a hypothetical pre-social condition. (Even non-metaphysical Hegelians basically suggest that the social order is merely legitimate insofar as present-day individuals can interpret the history of their norms as having been rational.) Even if it were possible to create a social order purely out of the collective and independent decision of a people (Hegel believes the French Revolution was closest to this scenario), such an attempt is necessarily flawed for Hegel, precisely because freedom is merely a matter of form, consisting in the fact that individuals collectively decided, rather than what they decided on. One can only continue living this freedom of choice by constantly recreating new moments of free choice, continually revolutionizing society-which Hegel famously regarded as the problem of the French Revolution. To realize the greatest degree of freedom, Hegel suggests, individuals should want a social system that is inclusive and harmonious, where they have the institutionalized means for furthering their group interests and they collectively oversee the overall system. Individuals can thus shape their social roles and interactions, while other forms of individuality that do not require negotiation are guaranteed their free expression. The universal good consists in nothing but such a system.

\section{Conclusion}

In contrast to the early Marx, Hegel focuses on diversity or individual distinctions between human beings (and groups), rather than on individuals as persons. He believes that such distinctions can only exist for oneself and for others if they are socially defined. While it is impossible for all individuals to take part in law making, Hegel argues that these (group) distinctions can and ought to be represented. Hegel chooses one's labour as the distinction that should be represented in the 'assembly of estates'. The reason is certainly that one's work is an important part in an individual's everyday life and that different labours are so systematically intertwined that it is impossible to change your own working conditions and relations without changing those of others as well.

Even though Marx validates individuals by demanding that they should personally take part in law making, his argument ultimately suggests that individuals do not have particular interests and that the universal good is what each individual would want if she were to identify completely with society or humanity as a whole. In a contradictory way, Marx validates individuals by encouraging them to lose their individuality. Hegel, for his part, agrees that the universal good is more than the mass of individual interests. And yet he proposes that the universal good is more in the sense of a harmonious organization of 


\section{Charlotte Baumann}

those interests. In order for individuality to be validated, distinct interests must be recognized and coordinated, thereby formulating the universal good.

While Marx's model relies on the idea of approval to make the universal good legitimate, Hegel suggests that it is not primarily a matter of approval, but of empowerment of interests and of the material and other benefits for individuals. Hegel is well aware that social roles limit individual freedom, requiring individuals to act out a role, as Marx criticizes. However, roles and patterns of interactions are unavoidable for Hegel. Freedom can only be ensured if individuals can shape their roles and the patterns of interactions by means of negotiation with others. This is more empowering than appealing to the individual's approval of her social system. Even in the best case of a direct democracy, a minority 'no'-vote will have no effect on the social system-while a coordination of interests requires taking all interests into account in a systematic manner.

\section{Charlotte Baumann \\ Technische Universität Berlin, Germany \\ Charlotte.Baumann@mail.com}

\section{Notes}

1 Abbreviations used (I have taken the liberty of amending the English translation where I saw fit):

Works by Hegel

E3 = Hegel, Philosophy of Mind, trans. W. Wallace (New York: Cosimo 2008)/Enzylklopädie der philosophischen Wissenschaften, volume III (Frankfurt: Suhrkamp, 1986).

PR $=$ Hegel, Elements of the Philosophy of Right, trans. H. B. Nisbet (Cambridge: Cambridge University Press, 1991)/Grundlinien der Philosophie des Rechts (Frankfurt: Suhrkamp, 1970).

$V G=$ Hegel, The Philosophy of History, trans. J. Sibree (Mineola NY: Dover Publications, 1956)/

Vorlesungen über die Philosophie der Geschichte (Frankfurt: Suhrkamp, 1986).

$V D=$ Hegel, 'The German Constitution', in Political Writings, trans. H. B. Nisbet (Cambridge: Cambridge University Press, 1971)/'Die Verfassung Deutschlands' in Frühe Schriften (Frankfurt: Suhrkamp, 1971).

VR1 = Hegel, Lectures on the Philosophy of Religion, volume 1, trans. R. F. Brown, P. C. Hodgson and J. M. Stewart (Oxford: Oxford University Press, 2007)/Vorlesungen über die Philosophie der Religion, volume 1 (Frankfurt: Suhrkamp, 1986).

WL2 = Hegel, Hegel's Science of Logic, trans. A. V. Miller (New York: Humanity Books, 1969)/ Wissenschaft der Logik, volume II (Frankfurt: Suhrkamp, 1969).

Works by Marx

MEW 1: 201-336 = Marx, 'Zur Kritik der Hegelschen Rechtsphilosophie', in Marx Engels Werke, volume 1 (Berlin: Dietz Verlag, 1956). 


\section{Hegel and Marx}

MEW 1: 347-77 = Marx, 'Zur Judenfrage', in Marx Engels Werke, volume 1 (Berlin: Dietz Verlag, 1956).

MEW 1: 378-81 = Marx, 'Zur Kritik der Hegelschen Rechtsphilosophie. Einleitung', in Marx Engels Werke, volume 1 (Berlin: Dietz Verlag, 1956).

MEW 1: 392-410 = Marx, 'Kritische Randglossen', in Marx Engels Werke, volume 1 (Berlin: Dietz Verlag, 1956).

$M E W 3$ = Marx and Engels, 'Die deutsche Ideologie', in Marx Engels Werke, volume 3 (Berlin: Dietz Verlag, 1990).

MEW 17 = Marx, 'Der Bürgerkrieg in Frankreich', in Marx Engels Werke, volume 17 (Berlin: Dietz Verlag, 1990).

MEW 23 = Marx, 'Das Kapital. Band 1', in Marx Engels Werke, volume 23 (Berlin: Dietz Verlag, 2005).

MEW 40 = Marx, 'Ökonomisch-philosophische Manuskripte', in Marx Engels Werke, volume 40 (Berlin: Dietz Verlag, 1990).

MEW 42 = Marx, Grundrisse der Kritik der Politischen Ökonomie, Marx Engels Werke, volume 42 (Berlin: Dietz Verlag, 1983).

${ }^{2}$ Hardimon suggests that individual interests are only furthered by the state in the sense that they are given their own sphere, namely civil society.

3 For Hegel's and Marx's opposition to liberalism, see Sayers 2007.

${ }^{4}$ Cf. Houlgate 2005, $204 \mathrm{f}$.

${ }^{5}$ For Hegel's criticism of democracy see also Brooks 2007, 116ff.

${ }^{6}$ Hegel is discussing the estates in this passage. The relevant sentence should be translated as: 'When organized as an organism, the mass attains its interests in a legitimate and orderly manner.' (Nisbet translates this somewhat misleadingly as 'When it becomes part of the organism, the mass...')

${ }^{7}$ Hegel claims that China and India precede history proper, as they merely present elements of statehood (VG: 116/147). The organicist or beautiful state of the Greek polis is the first state proper.

${ }^{8}$ Even in his Philosophy of Religion, Hegel insists that 'the caprice, the perversity, the indolence of individuals may interfere with the necessity of the universal spiritual nature' (VR1: 90/14).

\section{Bibliography}

Adorno, T. W. (2006), Zur Lehre von der Geschichte und von der Freibeit. Frankfurt a. M: Suhrkamp.

Avineri, S. (1972), Hegel's Theory of the Modern State. Cambridge: Cambridge University Press.

Baumann, C. (2011), 'Adorno, Hegel and the Concrete Universal', Philosophy \& Social Criticism 37:1: 73-94.

Beiser, F. (2005), Hegel. London: Routledge. 


\section{Charlotte Baumann}

Bowman, B. (2012), 'Labor, publicity and bureaucracy', in Hegel-Studien 47: 41-73.

Brooks, T. (2007), Hegel's Political Philosophy. Edinburgh: Edinburgh University Press. Chitty, A. (2000), 'Recognition and Social Relations of Production', in T. Burns and I. Fraser (eds.), The Marx-Hegel Connection. London: Palgrave MacMillan. Franco, P. (1999), Hegel's Philosophy of Freedom. New Haven CT: Yale University Press. Hardimon, M. (1994), Hegel's Social Philosophy: The Project of Reconciliation. Cambridge: Cambridge University Press.

Houlgate, S. (2005), An Introduction to Hegel: Freedom, Truth and History. Malden MA: Blackwell.

Lefebvre, H. (1969), Dialectical Materialism. London: Jonathan Cape Edition.

Leopold, D. (2007), The Young Marx: German Philosophy, Modern Politics, and Human Flourishing. Cambridge: Cambridge University Press.

Marcuse, H. (1967), Reason and Revolution. London: Routledge \& Kegan Paul Ltd. Neuhouser, F. (2000), Foundations of Hegel's Social Theory: Actualizing Freedom. London: Harvard University Press.

Patten, A. (1999), Hegel's Idea of Freedom. Oxford: Oxford University Press.

Pippin, R. (2000), 'What is the Question for which Hegel's Theory of Recognition is the Answer?' European Journal of Philosophy 8:2: 155-72.

Pippin, R. (2008), Hegel's Practical Philosophy: Rational Agency as Ethical Life. Cambridge: Cambridge University Press.

Sayers, S. (2007), 'Individual and Society in Marx and Hegel: Beyond the Communitarian Critique of Liberalism', Science \& Society 71:1: 84-107.

Taylor, C. (1975), Hegel. New York: Cambridge University Press. 